\author{
MAegORZATA SZYMAŃSKA ${ }^{1}$
}

\title{
Inicjatywy oparte na lokalnych zasobach - nowe wyzwania prawa rolnego
}

Intensyfikacja przekształceń obszarów wiejskich jest jednym z najważniejszych wyzwań współczesności. Europejski model wsi zakłada dywersyfikację jej struktury gospodarczej, a także dążenie do równowagi między aspektem ekonomicznym, społecznym i ekologicznym. Przyczynić ma się to do wzrostu poziomu jakości życia mieszkańców wsi, zapobiegać procesom jej wyludnienia oraz degradacji. Wśród licznych czynników wpływających na zrównoważony i wielofunkcyjny rozwój aktywność społeczności wiejskich nabiera istotnego znaczenia. Ponad 56\% ludności 27 państw członkowskich UE mieszka na obszarach wiejskich, które stanowią około $90 \%$ jej terytorium. W Polsce na tym terenie żyje 38,6\% ogółu ludności - jest to ogromny potencjał społeczny, polityczny i gospodarczy, zarówno w skali mikro-, jak i makroekonomicznej. Wielofunkcyjność rolnictwa to podstawowy warunek ożywienia rozwoju obszarów wiejskich w Polsce ${ }^{2}$. Jak wskazuje doktryna ${ }^{3}$, zrównoważony rozwój terytorialny ma na celu zapewnienie korzyści społecznościom lokalnym. Forum lokalne stanowi najlepsze miejsce prezentacji i realizacji projektów odzwierciedlających różnorodność terytoriów, kultur oraz populacji.

W Białej Księdze Komisji w sprawie przyszłości Europy z dnia 1 marca 2017 r. wezwano UE oraz jej państwa członkowskie do poprawy interakcji z obywatelami, ponoszenia wobec nich większej odpowiedzialności, a także szybszej i lepszej realizacji wspólnych uzgodnień m.in. w zakresie praw socjalnych. Stwierdzono również konieczność przestawienia się na nowe modele zrównoważonego wzrostu gospodarczego. Połączenie w sposób holistyczny i integracyjny aspektów gospodarczych, społecznych, środowiskowych oraz zapewnienie dóbr publicznych ma przyczynić

$1 \quad$ Uniwersytet Marii-Curie Skłodowskiej w Lublinie. Niniejsza publikacja stanowi zmodyfikowaną wersję artykułu, który ukaże się w Przeglądzie Prawa Rolnego. Publikacja dofinansowana ze środków Wydziału Prawa i Administracji Uniwersytetu Marii Curie-Skłodowskiej w Lublinie.

2 M. Bogusz, E. Kmita-Dziasek, Zagrody edukacyjne jako przykład innowacyjnej przedsiębiorczości na obszarach wiejskich, (w:) Innowacyjność w turystyce wiejskiej a nowe możliwości zatrudnienia na obszarach wiejskich, W. Kamińska (red.), Warszawa 2015, s. 156.

3 B. Jeżyńska, Slow city w zrównoważonym rozwoju obszarów wiejskich, (w:) Współczesne problemy prawa rolnego i cywilnego. Księga jubileuszowa Profesor Teresy Kurowskiej, D. Łobos-Kotowska, P. Gała, M. Stańko (red.), Warszawa 2018, s. 159 i n. 
się do dalszego rozwoju wspólnej polityki rolnej. Jak wskazuje się w dokumencie otwierającym debatę na temat przyszłości finansów $\mathrm{UE}^{4}$, polityka rolna powinna rozwijać się wielotorowo oraz zapewnić optymalne reakcje na wyzwania i możliwości, które pojawiają się na poziomie unijnym, krajowym, regionalnym, lokalnym, a także na poziomie gospodarstwa.

W dokumencie otwierającym debatę na temat przyszłości wspólnej polityki rolnej ${ }^{5}$ wskazano na konieczność dążenia do osiągnięcia przyszłego sukcesu rolnictwa i obszarów wiejskich w UE, a także nakreślono możliwy wkład w realizację celów determinujących rozwój całego społeczeństwa. Poprawa skuteczności realizacji polityki rolnej oraz jej aktualizacja umożliwiająca sprostanie wyzwaniom przyszłości, w szczególności poprzez inwestycje w usługi publiczne, infrastrukturę, umiejętności oraz budowanie potencjału pozwolą na stworzenie dynamicznej społeczności wiejskiej.

Polityka rozwoju wsi opiera się na podejściu oddolnym i terytorialnym, gdzie zakłada się uzgadnianie scenariuszy rozwoju między różnymi aktorami społecznymi. Mieszkańcy obszarów wiejskich stają się współodpowiedzialni za wyznaczanie oraz realizację szczegółowych wizji rozwoju danego terytorium.

Rozwój gospodarczy obszarów wiejskich oparty na zasadzie wielofunkcyjności, oprócz funkcji produkcyjnych przewiduje także rozwój ochrony środowiska, zachowanie naturalnego krajobrazu oraz tradycyjnych walorów kulturowych, co wpływa na realizację zadań i dokonywanie nakładów w sferach gospodarczych, społecznych oraz środowiskowych ${ }^{6}$. Osiągnięciu tych celów ma służyć również zastosowanie nowych narzędzi. Do najważniejszych z nich należą: inteligentne specjalizacje, zintegrowane inwestycje terytorialne oraz tzw. rozwój lokalny kierowany przez społeczność. Ma on umożliwić lokalnym podmiotom - obywatelom, partnerom gospodarczym i społecznym, organizacjom pozarządowym oraz samorządom uczestniczenie w określaniu strategii rozwoju na swoim obszarze, identyfikowaniu najważniejszych problemów, a także definiowaniu metod ich rozwiązywania. Potencjał rozwoju usług społecznych tkwi w polskim rolnictwie. Powinien on zostać wykorzystany na rzecz wielofunkcyjnego oraz zrównoważonego rozwoju obszarów wiejskich. Głównym czynnikiem mobilizującym rolników do podejmowania działalności pozarolniczej jest zdobycie dodatkowych dochodów, kompensujących niedostateczne wpływy finansowe z produkcji rolniczej. Motywacji ekonomicznej towarzyszyć mogą także cele społeczne, wynikające z potrzeby dzielenia z innymi

4 Dokument otwierający debatę na temat przeszłości finansów UE, Bruksela, 28.06.2017 r., COM (2017) 358 final.

5 Deklaracja Cork 2.0 z 2016 r. „Lepsze życie na obszarach wiejskich”, https://enrd.ec.europa.eu/sites/enrd/files/ cork-declaration_en.pdf (data dostępu: 20.08.2018).

6 D. Łobos-Kotowska, Jednostki samorządu terytorialnego jako beneficjenci środków Europejskiego Funduszu Rolnego na rzecz Rozwoju Obszarów Wiejskich, (w:) Samorząd terytorialny w procesie rozwoju gospodarczego obszarów wiejskich. 25 lat doświadczeń. Nowe wyzwania, P. Litwiniuk (red.), Warszawa 2015, s 136. 
wartości gospodarowania na roli i wiejskiego życia. Podejście takie stało się źródłem nowego nurtu zwanego rolnictwem społecznie zaangażowanym, które obejmuje działania wykorzystujące możliwości, jakie daje działalność rolnicza do wspierania terapii, rehabilitacji, integracji społecznej, kształcenia ustawicznego oraz usług socjalnych na obszarach wiejskich. Możliwość wykorzystania zaangażowania zarówno lokalnej społeczności, władz samorządowych, biznesu, jak też organizacji pozarządowych w wytyczaniu rozwoju gospodarczego, społecznego, przyrodniczego, kulturowego obszarów wiejskich stanowi skuteczny mechanizm rozwoju?

Modelowy wzorzec rozwoju obszarów wiejskich dostrzega konieczność rozwoju w oparciu o lokalne zasoby. Inwestowanie we wzrost kapitału społecznego nawiązuje do postulatów wdrażania zintegrowanego modelu rozwoju wsi, gdzie różne lokalne podmioty angażują się i współpracują na rzecz dobra wspólnego. Stawia to przed ustawodawcą konieczność rozwiązywania skomplikowanych problemów, uspołeczniania procesu podejmowania decyzji dotyczących lokalnego rozwoju. Wyzwania stoją również przed prawem rolnym. Ujmowanie prawa rolnego w kontekście wyzwań współczesności jest charakterystyczne dla tej gałęzi prawa. Swoistość regulacji związana jest z przedmiotem prawa rolnego, który należy rozpatrywać w aspekcie globalnym, regionalnym, krajowym oraz lokalnym. Współczesne wyzwania prawa rolnego zdeterminowane są przez cechy gospodarowania w rolnictwie, związane zwłaszcza z przyrodniczymi czynnikami produkcji rolnej, jak też rodzajem zaspokajanych potrzeb. Polityka rolna, konkretyzując te wyzwania, poszukuje na nie odpowiedzi oraz przesądza o wyborze celów, a także instrumentów do ich realizacji. Te ostatnie znajdują wyraz w postaci regulacji prawnych zaliczanych ze względu na przedmiot do prawa rolnego. Mając na uwadze relacje między rolnictwem, polityką i prawem możemy mówić o wyzwaniach prawa rolnego ${ }^{8}$.

W Polsce budowanie oddolnych partnerstw publiczno-prywatnych i społecznych (pomiędzy władzami samorządu terytorialnego, rolnikami, przedsiębiorcami, organizacjami pozarządowymi np. fundacjami, stowarzyszeniami czy osobami prywatnymi) jest całkiem nowym zagadnieniem i doświadczeniem dla społeczności obszarów wiejskich. Mieszkańcy obszarów wiejskich nie mieli możliwości, aby w tak szerokim zakresie, wspólnie oraz długofalowo oddziaływać lokalnie. Poprzez wykorzystanie zasobów lokalnych możliwe jest zrealizowanie ciekawych inicjatyw, nabycie doświadczeń przygotowujących do aplikowania o unijne środki w przyszłości. Przykładem interesujących i różnorodnych inicjatyw realizowanych przez lokalne grupy działania w naszym kraju są te o charakterze: kulturowym (konkursy chórów, kapel ludowych); historycznym (odtwarzanie walk, oznakowanie szlaków

$7 \quad$ M. Słodowa-Hełpa, Zrównoważony rozwój a konkurencyjność w wymiarze lokalnym, (w:) Zrównoważony rozwój lokalny: warunki rozwoju regionalnego i lokalnego, Stowarzyszenie Naukowe - Instytut Gospodarki i Rynku w Szczecinie, Szczecin 2010, s. 131-139.

8 R. Budzinowski, Prawo rolne wobec współczesnych wyzwań, „Przegląd Prawa Rolnego” 2014, s. 12. 
historii); architektonicznym (identyfikacja i dokumentacja zachowanych do dzisiaj młynów, karczm); przyrodniczym (wyznaczanie szlaków wędrówek ptasich); turystycznym (oznakowanie miejsc wędrówek pieszych, jazdy konnej, spływów kajakiem); ekonomicznym (zakładanie własnej działalności, tworzenie nowych miejsc pracy); społecznym (rewitalizacja kontaktów mieszkańców wsi); promocyjno-reklamowym czy chociażby edukacyjnym. Lokalne grupy działania są nową formą kapitału społecznego obszarów wiejskich, funkcjonując dla dobra publicznego, w oparciu o wspólne dla ich członków normy i wartości. Są strukturami otwartymi, formę kapitału społecznego, płaszczyzną umożliwiającą współdziałanie członków, opierającą się o podzielane normy i wartości oraz wzajemne zaufanie ${ }^{9}$.

Rozwój lokalny jest utożsamiany ze wzrostem poziomu obszarów słabo rozwiniętych, wyciąganiem ich z zacofania oraz przeciwdziałaniem marginalizacji i wykluczeniu. Takie stereotypowe podejście jest spojrzeniem bardzo wąskim, ograniczającym zakres i znaczenie rozwoju, niezgodnym z założeniami współczesnego modelu gospodarki. Coraz częściej akcentuje się bowiem, że to właśnie procesy na poziomie lokalnym mogą być szansą wzrostu gospodarczego oraz budowania przewagi konkurencyjnej regionów i całego kraju. W takich działaniach upatruje się dźwigni dla nowej gospodarki podlegającej mechanizmom globalnej konkurencyjności, opartej na wiedzy, kreatywności i innowacjach ${ }^{10}$.

W literaturze przedmiotu partnerstwo lokalne określone jest jako wszelkiego rodzaju przedsięwzięcia, inicjatywy, wspólnie planowane, wdrażanie i realizowanie w sposób ciągły w oparciu o innowacyjne metody oraz środki, ukierunkowane na rozwój lokalnego środowiska społeczno-gospodarczego, a także budowę tożsamości lokalnej i spójnego społecznie środowiska lokalnego ${ }^{11}$. Kluczową zasadą partnerstwa lokalnego jest różnorodność partnerów. Partnerzy wywodzą się z różnych sfer: publicznej, społecznej, gospodarczej, naukowej, przy czym katalog potencjalnych uczestników jest otwarty. U podstaw partnerstwa legło założenie skuteczności działań lokalnych przy rozwiązywaniu pojawiających się problemów społecznych, gospodarczych, środowiskowych, a także pokonywanie ujawniających się instytucjonalnych podziałów, wykluczenia społecznego ${ }^{12}$.

Partnerstwo lokalne pełni rolę płaszczyzny współpracy pomiędzy trzema kluczowymi dla funkcjonowania obszarów wiejskich sektorami: publicznym, społecznym i gospodarczym. Międzysektorowa formuła współpracy wywodzi się z do-

9 J. Małek, Turystyka kulturowa jako czynnik rozwoju lokalnego, „Prace i Studia Geograficzne”, tom 32, Warszawa 2003, s. 13 i n.

10 P. Kościelecki, Kultura w regionach - analiza dokumentów strategicznych polskich województw oraz piśmiennictwa przedmiotu, „Studia Regionalne i Lokalne” 2007, nr 3, s. 32 i n.

11 A. Sobolewski, Przez współprace do sukcesu. Partnerstwo lokalne na rynku pracy, Warszawa 2007, s. 10.

12 S. Pastuszka, Znaczenie partnerstwa publiczno-prywatnego dla przedsięwzięć finansowanych z funduszy europejskich, „Studia Regionalne i Lokalne” 2005, nr 2, s. 64. 
świadczeń powstałych $w$ ramach realizacji różnorodnych inicjatyw ${ }^{13}$. Umiejętność efektywniejszego wykorzystania zasobów przyrodniczych, kulturowych, społecznych - a zwłaszcza pobudzenia tego ogromnego kapitału ludzkiego do aktywniejszego działania na rzecz własnych małych ojczyzn - jest trudnym, ale i koniecznym działaniem. Jednak poprzez wypracowanie metody Leader i wykorzystanie w niej różnorodnych instrumentów możliwe było: oddolne wyznaczenie strategicznych dla danych regionów koncepcji rozwoju obszarów wiejskich, wykorzystanie wiedzy, doświadczenia i umiejętności zarządzania wielu ludzi, przedstawicieli różnorodnych środowisk społecznych w kierunku poprawy jakości ich życia na wsi, odnowienie więzi i współdziałania na rzecz rozwoju gospodarczego obszarów wiejskich.

Kapitał społeczny obszarów wiejskich charakteryzuje się oddolnością działań, lokalnością i terytorialnością inicjatyw, zintegrowanym podejściem, partnerskim działaniem poprzez lokalne grupy działania, innowacyjnością rozwiązywania problemów, samodzielnym zarządzaniem oraz finansowaniem działań. To także tworzenie powiązań i współpracy lokalnych grup działania na poziomie regionalnym, krajowym oraz międzynarodowym. Zachęca to społeczności lokalne do wspólnego działania na rzecz zmiany swojego otoczenia, rozwiązania pilnych problemów, inwestowania w działalności dywersyfikujące ich dochody, np. poprzez drobną przedsiębiorczość, zakładanie pozarolniczej działalności, agroturystykę, wioski tematyczne, gospodarstwa opiekuńcze, produkcję produktów wysokojakościowych, tradycyjnych, regionalnych, ekologicznych, rękodzieła ludowego, rzemiosła. Współpraca w ramach lokalnych grup działania przyczyniała się do wzrostu świadomości mieszkańców obszarów wiejskich, w przezwyciężaniu poczucia bierności, bezradności. Oczywiście, poza pozytywnymi i skutecznymi mechanizmami aktywizacji mieszkańców wsi oraz rozwoju tychże terenów, lokalne grupy działania przyczyniły się do zbudowania ogromnego zaplecza potencjału i więzi społecznych, kapitału społecznego ${ }^{14}$.

Podstawową przesłankę rozwoju lokalnego opartego na czynnikach endogenicznych stanowi pełne i harmonijne wykorzystanie zasobów kulturowych danego obszaru. Coraz częściej dziedzictwo kulturowe i przyrodnicze nie jest już traktowane jako balast i hamulec rozwoju, lecz jako potencjał i katalizator pozytywnych zmian. Co więcej, dziedzictwo okazuje się ważnym czynnikiem rozwoju społecznego i ekonomicznego. Przyrodnicze, kulturowe oraz historyczne zasoby regionu stanowią podstawę kreowania regionalnych produktów turystycznych, które przez utożsamianie z regionem są atrakcyjne oraz konkurencyjne na rynku turystycznym.

\footnotetext{
13 M. Kalisiak-Mędelska, Partnerstwo lokalne - istota i znaczenie na przykładzie lokalnych grup działania, Biblioteka Regionalisty 2013, nr 13, s. 74.

14 M. Słodowa-Hełpa, Inteligentna specjalizacja polskich regionów - warunki, wyzwania i dylematy, „Roczniki Nauk Społecznych" 2013, t. 41(5), nr 1.
} 
Jak wskazuje się w literaturze, w rozwoju obszarów wiejskich coraz większe znaczenie mają działania zmierzające do kreowania nowych lub rozwijania istniejących już usług, które wynikają z różnorodnych działań. U podstaw każdego działania zmierzającego do rozwoju obszarów wiejskich leży regularne wprowadzanie innowacji, wynikające ze zmieniającego się ujęcia elementów materialnych i niematerialnych tworzących ich tożsamość.

Do innowacyjnych działań na obszarach wiejskich zaliczyć można: ekomuzea, gospodarstwa enoturystyczne, szlaki kulturowe, szlaki kulinarne, wioski tematyczne, zagrody edukacyjne, zagrody rzemieślnicze, gospodarstwa opiekuńcze.

Wioska tematyczna to lokalna inicjatywa społeczno-gospodarcza, w wyniku której mieszkańcy tworzą ofertę turystyczną opartą na wybranym temacie przewodnim. Długofalowe oraz konsekwentne rozwijanie przez organizatorów programu wizyty w wiosce, opartego na wybranej tematyce, przyczynia się do tworzenia wizerunku miejscowości. Dzięki tym działaniom miejscowość, w której prowadzona jest wioska tematyczna, staje się ośrodkiem turystycznym opartym na pomysłowości, wiedzy i kreatywności mieszkańców zaangażowanych w jej działalność. Relatywnie korzystna relacja nakładów do efektów jest atutem wioski tematycznej. Działalność wioski opiera się na oryginalnym pomyśle oraz wykorzystaniu dostępnych zasobów. Szeroko rozumianymi zasobami mogą być m.in. szczególne zainteresowania i umiejętności mieszkańców, walory krajobrazowe oraz lokalne lub zapożyczone dziedzictwo kulturowe ${ }^{15}$.

Wioska tematyczna na płaszczyźnie gospodarczej jest przykładem tworzenia alternatywnych wobec rolnictwa źródeł utrzymania dla mieszkańców wsi i wpisuje się w nurt rozwijającej się współcześnie turystyki wiejskiej. Wioski tematyczne są odpowiedzią na postulowaną w ostatnich latach potrzebę rozwijania pozarolniczych funkcji gospodarczych wsi. ${ }^{16}$

Działalność wioski tematycznej nie ogranicza się jednak do rozwijania działalności gospodarczej w społecznościach wiejskich. Wioska tematyczna jest przedsięwzięciem interdyscyplinarnym. Do jego analizy mogą znaleźć zastosowanie takie dyscypliny naukowe, jak: organizacja i zarządzanie, teoria polityki, filozofia, psychologia społeczna czy socjologia. Analizy te mogą odnosić się zarówno do międzypodmiotowych relacji między organizatorami wioski tematycznej, jak i kontaktu wioski tematycznej z jej otoczeniem - osobami i organizacjami z zewnątrz. Relacje te można rozpatrywać z perspektywy edukacyjnej, w której szczególną rolę odgrywa proces nabywania nowych kompetencji przez mieszkańców zaangażowanych w tworzenie wioski. Proces uczenia się przez działalność w wiosce tematycznej może być również analizowany jako forma aktywizacji zawodowej na rynku pra- 
cy lub sposób przekwalifikowania się mieszkańców - odejścia od pracy na roli do obsługi ruchu turystycznego. Tworzenie i działalność wiosek tematycznych wpisują się w proces odnowy wsi zmierzający do poprawy jakości życia jej mieszkańców oraz dostosowania wsi do zmieniających się warunków życia i gospodarowania, w szczególności rosnącej współcześnie roli kapitału ludzkiego, społecznego i kulturowego. Szczególną rolę w działalności wioski tematycznej odgrywa kapitał społeczny, który wpływa na ekonomiczne i obywatelskie aspekty wspólnot lokalnych, gdyż tworzy warunki do współpracy jednostek w środowisku lokalnym. Teoria kapitału społecznego mówi, że utrzymywanie regularnych kontaktów z innymi ludźmi oraz podejmowanie działań dla osiągnięcia wspólnych celów prowadzi do trwałych i pozytywnych skutków dla działających jednostek i społeczności. W ten sposób zaspokajane są potrzeby, jak też wzmacniane więzi i zaufanie między ludźmi ${ }^{17}$. Wioska tematyczna, która angażuje do długoterminowej współpracy mieszkańców miejscowości, może przyczyniać się do tworzenia kapitału społecznego. Jest swoistym połączeniem działań przedsiębiorczych i społecznych łączących innowacyjność ekonomiczną i społeczną w postaci społecznego zaufania, sieci współpracy i zaangażowania w działalność wioski.

Inicjatywa powstania wioski tematycznej nie zawsze wynika z potrzeb ekonomicznych. Impulsem do ich powstania jest chęć ożywienia życia społecznego i kulturalnego wsi. Zaangażowanie się w tworzenie wioski tematycznej uczy nowych postaw i wzmacnia poczucie własnej wartości. Ludzie zaczynają wychodzić z domu, zaczynają ze sobą rozmawiać, odkrywają swoje zdolności. Charakterystyczną cechą takich specjalizacji branżowych społeczności lokalnych czy wsi tematycznych są rozwinięte nieformalne więzi społeczne oraz zasiedziałość mieszkańców, które podtrzymują atmosferę zaufania oraz umożliwiają przekazywanie wartości kulturowych i umiejętności technicznych następcom ${ }^{18}$. Inicjatywy oparte na lokalnych zasobach przyczyniają się do wielofunkcyjnego oraz zrównoważonego rozwoju obszarów wiejskich.

W zakres rolnictwa społecznego, inicjatyw opartych na lokalnych zasobach wpisuje się oferta edukacyjna gospodarstw rolnych, której urzeczywistnieniem w Polsce są zagrody edukacyjne ${ }^{19}$. Celem działalności zagród edukacyjnych jest przybliżenie społeczeństwu naturalnego środowiska gospodarstwa wiejskiego, a także przekazanie wiedzy na temat pochodzenia żywności i trudu jej wytwarzania, a pośrednio także budowanie rynku świadomych konsumentów. Konkretne cele edukacyjne realizowane są na bazie infrastruktury i zasobów rolniczych w gospodarstwie oraz jego przyrodniczo-kulturowego otoczenia. Jak wskazuje się

17 Ibidem.

18 B. Domański, Czynniki społeczne w lokalnym rozwoju gospodarczym we współczesnej Polsce, (w:) Wybrane problemy badawcze geografii społecznej w Polsce, I. Sagan, M. Czepczyński (red.), Gdańsk 2001, s. 130.

19 M. Bogusz, E. Kmita-Dziasek, Zagrody edukacyjne jako przykład innowacyjnej przedsiębiorczości na obszarach wiejskich, http://www.czasopisma.pan.pl/Content/97622/mainfile.pdf (data dostępu: 20.08.2018). 
w literaturze, pojęcie gospodarstwa edukacyjnego wraz z jego identyfikacją rynkową „Zagroda edukacyjna” zostało zdefiniowane w wyniku ogólnopolskiego projektu prowadzonego przez Centrum Doradztwa Rolniczego Oddział w Krakowie i zatwierdzone przez Ministerstwo Rolnictwa i Rozwoju Wsi w listopadzie 2011 r., a jego wdrożenie zaowocowało utworzeniem Ogólnopolskiej Sieci Zagród Edukacyjnych. Pod pojęciem zagroda edukacyjna kryją się gospodarstwa wiejskie posiadające zwierzęta gospodarskie lub uprawy rolnicze przeznaczone do prezentacji dla grup dzieci i młodzieży przyjmowanych w ramach programów szkolnych lub udostępniane jako atrakcja turystyczna dla rodzin z dziećmi i dorosłych podróżujących indywidualnie oraz realizujące programy edukacyjne w zakresie co najmniej dwóch dziedzin: produkcja roślinna, produkcja zwierzęca, przetwórstwo płodów rolnych, edukacja ekologiczna i konsumencka, czy dziedzictwo kultury materialnej wsi, tradycyjne zawody, rękodzieło i twórczość ludowa. Przynależność do sieci jest dobrowolna i odbywa się na podstawie aplikacji indywidualnego obiektu oraz rekomendacji uprawnionego pracownika właściwego terytorialnie Ośrodka Doradztwa Rolniczego. Zagroda edukacyjna może być prowadzona przez osoby fizyczne - rolników indywidualnych lub przez stowarzyszenia, koła gospodyń wiejskich, spółki czy spółdzielnie. Cele programowe zagród edukacyjnych mogą być realizowane jako główna działalność gospodarstwa lub jako działalność dodatkowa, uzupełniająca podstawową działalność produkcyjną czy agroturystyczną. Wyróżnia się dwie formy organizacyjne gospodarstw edukacyjnych, skutkujące dla ich właścicieli odmiennymi obowiązkami prawno-finansowymi. Gospodarstwo edukacyjne może być uzupełnieniem oferty gospodarstwa agroturystycznego albo stanowić wyspecjalizowaną działalność edukacyjną niezależną od usług turystycznych ${ }^{20}$. Świadczone usługi edukacyjne bądź usługi wynikające bezpośrednio z prowadzonej działalności oraz dochód ze sprzedaży produktów rolnych w formie przetworzonej i nieprzetworzonej mogą być wynagrodzeniem z prowadzenia zagrody edukacyjnej. W zależności od form prowadzenia, świadczenia usług i sprzedaży wytworzonych towarów podlegają one odrębnym regulacjom prawnym.

W doktrynie powszechnie uznaje się, iż Ogólnopolska Sieć Zagród Edukacyjnych powstała w wyniku poszukiwania nowych motywacji dla rolników do kontynuowania działalności rolniczej oraz z przekonania, że gospodarstwo rolne ma unikatowy potencjał do prowadzenia atrakcyjnych zajęć edukacyjnych wychodzących naprzeciw potrzebie przybliżenia globalnemu społeczeństwu pracy rolnika i źródeł pochodzenia żywności ${ }^{21}$.

Przykładem rolnictwa społecznego, inicjatyw opartych na lokalnych zasobach są także gospodarstwa opiekuńcze. Działalność opiekuńcza będzie z pewnością

21 E. Kmita-Dziasek, Organizacja i funkcjonowanie Ogólnopolskiej Sieci Zagród Edukacyjnych. Materiały informacyjne, II Ogólnopolski Zlot Zagród Edukacyjnych, Centrum Doradztwa Rolniczego, Kraków 2014, s. 4. 
szczególnie atrakcyjna dla małych gospodarstw, które silniej odczuwają potrzebę znalezienia swojego miejsca na rynku. Wzbogacenie oferty gospodarstw rolnych o nowe funkcje pozwoli na rozwiązanie problemów w dostępie do usług społecznych, które dotykają wiele miejscowości i regionów. Problemy te są poważnym zagrożeniem w kontekście przybierających na sile niepokojących zjawisk, takich jak starzenie się społeczeństwa. Koncepcja rozwoju gospodarstw opiekuńczych zakłada, że muszą być one racjonalnymi ekonomicznie podmiotami, których prowadzenie powinno zapewniać dodatkowe dochody rolnikom. Wizja uzyskania takich dochodów nie może być jednak jedyną motywacją do podejmowania działalności, która jest tak wymagająca i wiąże się z licznymi wyzwaniami. Działalność opiekuńcza będzie miała ograniczoną efektywność ekonomiczną ze względu na stałe, wysokie koszty jej prowadzenia oraz ograniczony zakres. Zwiększenie dochodów byłoby tu możliwe głównie poprzez przyjmowanie coraz większej liczby podopiecznych, co jest oczywiście ograniczone przez infrastrukturę danego gospodarstwa, jak również przez same realia świadczenia opieki. $Z$ tego względu koncepcja powstawania i rozwoju gospodarstw opiekuńczych kierowana jest do tych osób, które znając trudności związane z opieką, będą skłonne poświęcić się tej pracy i czerpać z niej dodatkową, pozafinansową satysfakcję. Istotnym argumentem przemawiającym za rozwojem gospodarstw opiekuńczych jest fakt, że kontakt z naturą, walory wiejskiego środowiska oraz specyficzne zasoby kulturowe dają podstawę do tworzenia usług wysokiej jakości, które w realny sposób będą wpływać na jakość życia korzystających z nich osób ${ }^{22}$.

Pogodzenie działalności rolniczej z opieką nad osobami potrzebującymi wsparcia oraz samo uruchomienie gospodarstwa opiekuńczego będzie z pewnością olbrzymim wyzwaniem dla większości zainteresowanych. Nie ulega wątpliwości, że powodzenie gospodarstw opiekuńczych w Polsce w dużej mierze będzie zależeć od wsparcia i systemu zachęt, jaki zostanie dla nich stworzony.

Są one wzorem i inspiracją do kolejnych działań oraz efektywnym sposobem propagowania na obszarach wiejskich nowych idei. Dodatkowo umożliwiają one testowanie wypracowywanych rozwiązań. Podejmowanie przez rolników działań wspierających rozwój społeczności lokalnych będzie owocowało także wzmocnieniem ich pozycji w społecznościach lokalnych oraz skutkowało poprawą wizerunku rolnictwa.

Należy również wskazać na ekonomiczny wymiar rozwoju gospodarstw opiekuńczych. Będą one wspierać rozwój lokalnych gospodarek oraz będą szansą dla rolników na dywersyfikację i zwiększenie dochodów. 
Wyzwania stojące u podstaw rozwoju prawa rolnego powinny być ukierunkowane na określone cele gospodarcze, społeczne, środowiskowe, a jednocześnie odzwierciedlać potrzeby i aspiracje mieszkańców obszarów wiejskich. Przyszłe działania podejmowane w różnych obszarach polityki rolnej powinny dążyć do rozwoju kapitału społecznego na obszarach wiejskich, tak aby wspierać potencjał ludności mieszkającej na danym obszarze.

Konieczne są dalsze rozważania na temat roli i efektywnego działania kapitału społecznego, w szczególności na obszarach wiejskich. Odpowiednia, świadomie kształtowana polityka rozwoju obszarów wiejskich i rolnictwa wymaga nie tylko typowo ekonomicznego ukierunkowania. Istotne jest również wsparcie pozostałych funkcji, jakie pełnią obszary wiejskie, a te są mocno zróżnicowane i potrzebne dla ogółu społeczeństwa, a nie tylko mieszkańców wsi. Zaowocują one dalszą współpracą mieszkańców wsi, zbudują trwały dialog kultur, obyczajów, tradycji, religii, pokoleń, odkrywając drzemiące lub zapomniane możliwości. Powstające na obszarach wiejskich zrównoważone łańcuchy wartości oparte na lokalnych zasobach stanowią dla mieszkańców danych terenów szansę na zróżnicowanie działalności, a także zapewniają dodatkowy dochód. Polityka rolna powinna w coraz większym stopniu koncentrować się na wspieraniu tego rodzaju działań. Oddolne, realizowane na szczeblu lokalnym działania są skutecznym sposobem budowania lokalnego potencjału, a także wspierania włączenia społecznego, ograniczenia ubóstwa również przez tworzenie miejsc pracy. Synergia i koordynacja działań mieszkańców wsi z władzami samorządowymi oraz przedsiębiorcami przyczyni się do uruchomienia potencjału obszarów wiejskich. Wyzwaniem jest wsparcie mechanizmów weryfikowania wpływu określonych rozwiązań na sytuację obszarów wiejskich, który zapewnia systematyczny przegląd strategii politycznych z perspektywy obszarów wiejskich oraz społeczności mieszkającej na danym terytorium. Jak wskazuje się w literaturze ${ }^{23}$, rozwojowi ustawodawstwa rolnego powinien towarzyszyć rozwój badań naukowych, w szczególności nauka prawa rolnego, która - we współpracy z innymi naukami - może wspierać wielofunkcyjny oraz zrównoważony rozwój obszarów wiejskich, determinowany przez kapitał społeczny określonego terytorium. 


\section{INITIATIVES BASED ON LOCAL RESOURCES \\ - NEW CHALLENGES OF AGRICULTURAL LAW}

Keywords: rural development, local resources, social capital

Model of rural development recognizes the necessity of local development based on local resources. Investing in the growth of social capital refers to the postulates of implementing an integrated model of rural development, where different local actors engage and cooperate for the common good. Challenges also face agricultural law.

The social capital of rural areas is characterized by the bottom-up activities, locality and territoriality of initiatives, integrated approach, partnership action through local action groups, innovation in problem solving, independent management and financing of activities. It encourages local communities to work together to change their surroundings, solve urgent problems, invest in activities diversifying their income, for example through small entrepreneurship, setting up non-agricultural activities, agritourism, thematic villages, care farms, production of traditional, regional and ecological high quality products, folk handicrafts, crafts.

\section{Bibliografia:}

Bogusz M., Kmita-Dziasek E., Zagrody edukacyjne jako przykład innowacyjnej przedsiębiorczości na obszarach wiejskich, (w:) Innowacyjność w turystyce wiejskiej a nowe możliwości zatrudnienia na obszarach wiejskich, W. Kamińska (red.), Warszawa 2015.

Bogusz M., Kmita-Dziasek, E., Zagrody edukacyjne jako przykład innowacyjnej przedsiębiorczości na obszarach wiejskich, http://www.czasopisma.pan.pl/Content/97622/mainfile.pdf (data dostępu: 20.08.2018).

Budzinowski R., Prawo rolne wobec współczesnych wyzwań, „Przegląd Prawa Rolnego” 2014, nr 2.

Domański B., Czynniki społeczne w lokalnym rozwoju gospodarczym we współczesnej Polsce, (w:) Wybrane problemy badawcze geografii społecznej w Polsce, I. Sagan, M. Czepczyński (red.), Gdańsk 2001.

Idziak W., Wymyślić wieś od nowa. Wioski tematyczne, Koszalin 2008.

Jeżyńska B., Slow city w zrównoważonym rozwoju obszarów wiejskich, (w:) Współczesne problemy prawa rolnego i cywilnego. Księga jubileuszowa Profesor Teresy Kurowskiej, D. Łobos-Kotowska, P. Gała, M. Stańko (red.), Warszawa 2018.

Jurczyk-Miżejewska A., Stępnik K., Król J., Działania na rzecz rozwoju gospodarstw opiekuńczych w Polsce na poziomie regionalnym i lokalnym, http://www.gospodarstwa-opiekuncze.pl (data dostępu: 20.08.2018).

Kalisiak-Mędelska M., Partnerstwo lokalne - istota i znaczenie na przykładzie lokalnych grup działania, Biblioteka Regionalisty 2013, nr 13. 
Kmita-Dziasek E., Organizacja i funkcjonowanie Ogólnopolskiej Sieci Zagród Edukacyjnych. Materiały informacyjne, II Ogólnopolski Zlot Zagród Edukacyjnych, Centrum Doradztwa Rolniczego, Kraków 2014.

Kościelecki P., Kultura w regionach - analiza dokumentów strategicznych polskich województw oraz piśmiennictwa przedmiotu, „Studia Regionalne i Lokalne” 2007, nr 3.

Łobos-Kotowska D., Jednostki samorządu terytorialnego jako beneficjenci środków Europejskiego Funduszu Rolnego na rzecz Rozwoju Obszarów Wiejskich, (w:) Samorząd terytorialny w procesie rozwoju gospodarczego obszarów wiejskich. 25 lat doświadczeń. Nowe wyzwania, P. Litwiniuk (red.), Warszawa 2015.

Małek J., Turystyka kulturowa jako czynnik rozwoju lokalnego, „Prace i Studia Geograficzne”, tom 32, Warszawa 2003.

Pastuszka S., Znaczenie partnerstwa publiczno-prywatnego dla przedsięwzięć finansowanych z funduszy europejskich, „Studia Regionalne i Lokalne” 2005, nr 2.

Purchla J., Dziedzictwo kulturowe a kapitał społeczny, „Małopolskie Studia Regionalne” 2011, nr 1.

Słodowa-Hełpa, M., Zrównoważony rozwój a konkurencyjność w wymiarze lokalnym, (w:) Zrównoważony rozwój lokalny: warunki rozwoju regionalnego i lokalnego, Stowarzyszenie Naukowe - Instytut Gospodarki i Rynku w Szczecinie, Szczecin 2010.

Słodowa-Hełpa M., Inteligentna specjalizacja polskich regionów - warunki, wyzwania i dylematy, „Roczniki Nauk Społecznych” 2013, t. 41(5), nr 1.

Sobolewski A., Przez współprace do sukcesu. Partnerstwo lokalne na rynku pracy, Warszawa 2007.

Zajda K., Nowe formy kapitału społecznego wsi. Studium przypadku lokalnych grup działania z województwa łódzkiego, Łódź 2011. 